\title{
Effects of repeated extracorporeal shock wave in urinary biochemical markers of rats ${ }^{1}$
}

\author{
Avaliação dos fatores bioquímicos urinários de risco para nefrolitíase em ratos submetidos à \\ aplicação repetida de ondas de choque eletro-hidráulicas
}

\author{
Márcio Carvalho', Luiz Gonzaga de Freitas Filho ${ }^{\text {II }}$, Maurício Carvalho ${ }^{\text {III }}$, Djalma José Fagundes ${ }^{\text {IV }}$, Valdemar Ortiz \\ ${ }^{\text {I }}$ Fellow Master degree, Department of Surgery, UNIFESP, Sao Paulo, Brazil. \\ ${ }^{\text {II }}$ Affiliate Professor, Department of Surgery, UNIFESP, Sao Paulo, Brazil. \\ III Associate Professor, Department of Medicine, State University of Maringa, PR, Brazil. \\ ${ }^{\text {IV }}$ Associate Professor, Department of Surgery, UNIFESP, Sao Paulo, Brazil. \\ ${ }^{\vee}$ Chair of Urology, Department of Surgery, UNIFESP, Sao Paulo, Brazil.
}

\begin{abstract}
Purpose: To access the effect of repeated extracorporeal shock wave (ESW) on urinary biochemical markers Methods: 20 rats were assigned for ESW (Direx Tripter X1 ${ }^{\circledR}-14 \mathrm{KV}$ ) to one of two groups: G1 (n=10) one ESW; G2 (n=10) two ESWs within a 14-day interval. Within the twenty-four hour period before and after the application of shock waves, the animals were placed in metabolic cages for 24 hour urine collection. The ph, creatinine, sodium, potassium, chlorides, calcium, magnesium, phosphorus, oxalates, alkaline phosphatase and citrates were measured. Twenty-four hours after the material was collected for urinary determination, the animals underwent nephrectomy of the kidney submitted to the ESW applications and were, then, sacrificed. The kidneys were processed for hispatological examination. Results: Small variations in the biochemical markers were found in both groups, with no significant differences between the values obtained either prior to or following the ESW applications, except for citrate and alkaline phosphatase. Citraturia decreased significantly in group 2, following the second ESWL application $(24.8 \pm 3.0 \mathrm{mg} /$ day after the first ESWL vs. 15.3 $\pm 2.2 \mathrm{mg} /$ day after the second ESWL; $\mathrm{p}<0.05)$. Alkaline phosphatase increased significantly following ESWL in group I $(0.57 \pm 0.02$ vs. $0.79 \pm 0.04 \mu \mathrm{mol} / \mathrm{mg}$ creatinine; $\mathrm{p}<0.01)$ and also in group $2(0.69 \pm 0.05 \mathrm{vs} .0 .83 \pm 0.03 \mu \mathrm{mol} / \mathrm{mg}$ creatinine; $\mathrm{p}<0.05)$. Glomerular, interstitial and sub-capsular hemorrhage with perivascular edema was found in the animals in both groups studied. Conclusions: A significant increase in urinary alkaline phosphatase was found in both groups studied, suggesting a proximal tubule lesion. In the group of rats undergoing more than one ESWL application, a smaller urinary citrate excretion was noticed, which may be a factor contributing for the formation of new calculi.
\end{abstract}

Key words: Urologic Diseases. Lithiasis. Lithotripsy. Biological Markers. Rats.

\section{RESUMO}

Objetivo: Avaliar os efeitos renais das ondas de choque eletro-hidráulicas (OCEH), utilizando como parâmetros marcadores bioquímicos urinários. Métodos: Foram utilizados 20 ratos machos, EPM - Wistar, distribuídos aleatoriamente em dois grupos: G1 (n=10) Animais submetidos a uma sessão de OCEH. G2 (n=10) Animais submetidos a duas sessões de OCEH separadas por um intervalo de 14 dias. Para coleta da urina os animais foram mantidos em gaiolas metabólicas 24 horas antes e depois da aplicação das OCEH. Foram medidos o pH, a creatinina, sódio, potássio, cloretos, cálcio, magnésio, fósforo, oxalato, fosfatase alcalina e citrato. Vinte e quatro horas após a coleta da urina os animais foram submetidos à nefrectomia do rim envolvido no experimento e, em seguida, sacrificados. Os rins foram então submetidos aos procedimentos de fixação e coloração histológica com hematoxilina e eosina. Resultados: Pequenas variações nos marcadores bioquímicos foram detectadas nos dois grupos, sem diferenças significantes nos valores obtidos antes e após a aplicação das $\mathrm{OCEH}$, exceto para os valores urinários de citrato e fosfatase alcalina. A citratúria diminuiu significantemente nos animais do Grupo 2 após a segunda aplicação das $\operatorname{OCEH}(24,8 \pm 3,0 \mathrm{mg}$ /dia após a primeira sessão de OCEH e 15,3 $\pm 2,2 \mathrm{mg} /$ dia após a segunda sessão de OCEH; $\mathrm{p}<0.05)$. A fosfatase alcalina urinária aumentou de forma significante no grupo 1 após a sessão de OCEH $(0,57 \pm 0,02$ vs. $0,79 \pm 0,04 \mu \mathrm{mol} / \mathrm{mg}$ de creatinina; $\mathrm{p}<0,01)$ e também no grupo $2(0,69 \pm 0,05 \mathrm{vs} .0,83 \pm 0,03 \mu \mathrm{mol} / \mathrm{mg}$ de creatinina; $\mathrm{p}<0,05)$. Os achados histológicos observados nos animais dos dois grupos foram: hemorragia glomerular, intersticial e subcapsular, acompanhada de edema perivascular. Conclusões: Observou-se um aumento significante da fosfatase alcalina urinária nos dois grupos estudados, sugerindo uma lesão dos túbulos proximais causada pelas ondas de choque eletro-hidráulicas. Nos animais submetidos a mais de uma sessão de OCEH observou-se um discreto aumento na excreção urinária de citrato, o que pode ser um fator que pode contribuir para a formação de novos cálculos.

Descritores: Doenças Urológicas. Litíase. Litotripsia. Marcadores Bioquímicos. Ratos.

${ }^{1}$ Research performed at the Laboratory of Experimental Surgery, Federal University of Sao Paulo (UNIFESP), Brazil. 


\section{Introduction}

The management of urolithiasis is based on the identification of both the baseline disease that made possible the formation of calculi and the use of medical substances that either alter the course of the baseline disease or modify the biochemical composition of the urine. Once the presence of the stone is found in the excretory routes, means must be found to eliminate it since, besides causing symptoms; it can give rise to complications such as obstruction, repeated infections and partial or total loss of the renal function. Although in the past twenty-five years there has been an improvement in the quality of endoscopy devices, enabling better access to the site where the stone is impacted, extracorporeal shock wave lithotripsy (ESWL) continues to be the only noninvasive treatment method $^{1-3}$.

ESWL is considered an effective procedure, highly successful in selected patients ${ }^{4-7}$. Despite its acknowledged efficacy, short and long term adverse effects have been reported, such as perirenal and sub-capsular hematoma, and even chronic alterations such as glomerularsclerosis and focal or segmentary parenchymatous fibrosis ${ }^{7-13}$. A transitory loss in the renal function has been reported in patients with normal renal function, which returns to normal after four days from the application of the extracorporeal shock waves; such alterations, however, may last longer in patients with an already compromised renal function.

Increased rates of recurrence following ESWL have been reported, and in some studies with a long term follow-up, approximately $70 \%$ of patients presented with at least one new stone $^{3,4}$. Fragments of post-ESWL remaining stones, immersed in supersaturated urine, would serve as nuclei for posterior new stone formation $^{15,14}$.

The number and intensity of the shock waves are potential lesion factors ${ }^{13-16}$. The consequences of the trauma imposed by the shock waves have been studied by using markers such as the urinary enzymes $\mathrm{N}$-acetyl-beta-glucosaminidase, beta-galactosidase, gama-glutamil-transferase and high molecular weight proteins (macroglobulins and calbidin D28K). Such enzymes however can be altered, in a brief and transitory fashion, after a single or sequential sessions of extracorporeal electromagnetic shock waves ${ }^{14-22}$. The presence of multiple renal stones or stones that fail to respond well to a single application of shock waves demands, within the short term, an ESWL reapplication. In such cases, the harmful effects may no longer be brief and they may alter the function in a consistent manner. Detecting an alteration in the biochemical composition of the urine may be a manner to assess the consequences of those alterations ${ }^{20}$.

This study aimed to observe the possible alterations in the biochemical composition of the urine of animals undergoing repeated applications of extracorporeal shock wave lithotripsy.

\section{Methods}

The experimental protocol was approved by the Ethics Committee of Federal University of Sao Paulo and follow the Council for International Organization of Medical Sciences (CIOMS) ethical code for animal experimentation (WHO Chrinicle 1985; 39(2):51-6) and the principles of the Brazilian College on Animal Experimentation (www.cobea.org.br). All surgical procedures and ESW were done under general anesthesia (intramuscular via) with ketamine (60 mg. $\left.\mathrm{kg}^{-1}\right)$ and xylasine (5 mg. $\left.\mathrm{kg}^{-1}\right)$.

Initially 20 male Wistar rats weighing between $250-270 \mathrm{~g}$ underwent laparotomy and a radiopaque device (a piece of radiopaque surgical gauze, $0.2 \mathrm{~cm}$ in diameter) was sutured at the adipose tissue situated in the anterior face of the right renal pelvis near the renal parenchyma. The standard position of the $\mathrm{X}$-ray marker was confirmed through the simple posteroanterior radiographic method.

The animals were randomly assigned to two groups:

Group 1 - $(\mathrm{N}=10)$ Animals undergoing one application of 2,000 electro-hydraulic shock waves of $14 \mathrm{Kv}$ intensity.

Group $2-(\mathrm{N}=10)$ Animals undergoing two applications of 2.000 electro-hydraulic shock waves of $14 \mathrm{Kv}$ intensity, with a 14-day interval.

On day fourteen postoperative, using the same anesthetic procedures, the animals in both groups were affixed to the lithotripsy table, underwent the shock waves application through a Direx Tripter $\mathrm{X} 1^{\circledR}$ device. The renal marker was located and focused in the fluoroscopy monitor and the lithotripsy device was then turned on. Two thousand shock waves of $14 \mathrm{KV}$ intensity were applied, generating a wave displacement in aqueous solution equal to 540 BAR, within approximately 30 minutes. After 14 days from the first application, the animals in group 2 underwent the second application of 2,000 shock waves in the same intensity and same technique, totaling 4,000 shock waves. Twenty-four hours before and after the shock waves application, the animals were placed in metabolic cages for a 24-hour urine collection. The urine collected was lyophilized for posterior analysis of all samples together. The ph, creatinine, sodium, potassium, chlorides, calcium, magnesium, phosphorus, oxalates, alkaline phosphatase and citrates were determined. $\mathrm{pH}$ was measured by using a $\mathrm{pH}$ potentiometer (Orion Research - Model 301), with three consecutive determinations, using the mean measurements. Creatinine was measured through the alkaline picrate method and photometric reading (Architect Ci 8200 - Abbott) and expressed in milligrams per deciliter (mg/dL). Sodium, chloride and potassium were measured by the selective electrode method (Architect - Ci 8200 - Abbott) and expressed in millimoles per liter $(\mathrm{mMol} / \mathrm{L})$. Calcium was measured by the colorimetric method (Architect - Ci 8200 - Abbott), by using ortho-cresolphthalein as indicator and expressed in milligrams per liter $(\mathrm{mg} / \mathrm{L})$. Urinary oxalate was measured by the Fraser \& Campbell method, modified and expressed in milligrams per $24 \mathrm{hs}$ (mg/24 hs), through spectrophotometer reading. Citrate was measured by modified Calamera's spectrophotometric reaction and expressed in milligrams per $24 \mathrm{hs}$ ( $\mathrm{mg} / 24 \mathrm{hs}$ ). Phosphorus was measured by the phosphomolybdate colorimetric method (Architect - Ci 8200 - Abbott) and expressed in milligrams per liter (mg/L). Magnesium was measured by the colorimetric method (Architect - Ci 8200 - Abbott) and expressed in milligrams per liter $(\mathrm{mg} / \mathrm{L})$. Uric acid was measured by the uricase UV method (Architect - Ci 8200 - Abbott) and expressed in milligrams per liter $(\mathrm{mg} / \mathrm{L})$. The alkaline phosphatase enzyme was measured by kinetic-enzymatic reaction, by using Byosis enzymatic-photometric kits (Architect - Ci 8200 - Abbott) and expressed in International Units per liter (UI/L).

Twenty-four hours after the collection of material for urinary measurement the animals were again anesthetized and underwent median laparotomy for the right nephrectomy to be 
performed. Euthanasia was performed by aortic section. Immediately following the nephrectomy, the kidneys were fixed in a $10 \%$ formalin solution, for 24 hours. The specimens were cleavaged and processed with progressive dehydration in ethyl alcohol, diafanized in xylol, impregnated by paraffin according to standard protocols.

Four-micra sections were made, placed in slides previously smeared with Meyer albumin and kept to dry in stoves regulated at $37^{\circ} \mathrm{C}$ temperature for 24 hours. Those sections were stained by the hematoxylin and eosin technique (HE). Subcapsular, interstitial and glomerular hemorrhage and perivascular edema were assessed to show that the shock wave had actually been applied in the renal parenchyma.

The urinary measurement values obtained were subject to the Kolmogorov-Smirnov test. As they failed to present normal distribution, we used the Mann-Whitney-Wilcoxon non-parametric test to compare the means before and after the ESWL application.
The results were expressed by the mean \pm standard deviation. Standard statistics software (Minitab 11.0, Minitab Inc., USA) was used. Statistical significance was considered at $5 \%$ level $(\mathrm{p}<0.05)$.

\section{Results}

The urinary electrolyte values found can be seen in Table 1. Slight variations were observed in both groups, with no significant differences between the values obtained prior to and following the ESW application, except for the citrate. Citraturia decreased significantly in group 2, after the second ESW application $(24.8 \pm 3.0 \mathrm{mg} /$ day after the first ESW vs. $15.3 \pm 2.2 \mathrm{mg} /$ day after the second ESW; $\mathrm{p}<0.05)$ ).

Alkaline phosphatase increased significantly following ESW in group I $(0.57 \pm 0.02$ vs. $0.79 \pm 0.04 \mu \mathrm{mol} / \mathrm{mg}$ creatinine; $\mathrm{p}<0.01)$ as well as in group $2(0.69 \pm 0.05 \mathrm{vs} .0 .83 \pm 0.03 \mu \mathrm{mol} / \mathrm{mg}$ creatinine post-ESW; $<<0.05)$.

TABLE1 - Urinary values in the two groups

\begin{tabular}{|c|c|c|c|c|}
\hline Urinary Values & $\begin{array}{c}\text { Group } 1 \\
\text { Before ESW }\end{array}$ & $\begin{array}{c}\text { Group } 1 \\
\text { After ESW }\end{array}$ & $\begin{array}{c}\text { Group } 2 \\
\text { Before ESW }\end{array}$ & $\begin{array}{c}\text { Grou } 2 \\
\text { After ESW }\end{array}$ \\
\hline $\mathrm{pH}$ & 7,73 & 7,72 & 7,77 & 7,79 \\
\hline $\mathrm{Na}$ (mmol/day) & $0,8 \pm 0,04$ & $0,7 \pm 0,02$ & $1,1 \pm 0,1$ & $1,0 \pm 0,2$ \\
\hline K (mmol/day) & $1,5 \pm 0,2$ & $1,2 \pm 0,4$ & $1,7 \pm 0,08$ & $1,6 \pm 0,2$ \\
\hline $\mathrm{CI}$ (mmol/day) & $1,2 \pm 0,5$ & $0,9 \pm 0,2$ & $0,9 \pm 0,35$ & $1,1 \pm 0,2$ \\
\hline P (mg/day) & $13 \pm 2,1$ & $15 \pm 1,3$ & $12 \pm 2,2$ & $11,7 \pm 1,5$ \\
\hline Mg (mg/day) & $1,8 \pm 0,7$ & $1,9 \pm 1,0$ & $1,4 \pm 0,9$ & $1,5 \pm 0,7$ \\
\hline $\mathrm{Ca}$ (mg/day) & $0,8 \pm 0,07$ & $0,8 \pm 0,09$ & $0,6 \pm 0,03$ & $0,7 \pm 0,04$ \\
\hline Creat (mg/day) & $9,5 \pm 0,6$ & $10 \pm 0,4$ & $8,5 \pm 0,7$ & $9,1 \pm 0,7$ \\
\hline $\begin{array}{l}\text { Uric Acid } \\
\text { (mg/day) }\end{array}$ & $1,17 \pm 0,37$ & $1,15 \pm 0,28$ & $1,09 \pm 0,63$ & $1,07 \pm 0,22$ \\
\hline $\begin{array}{l}\text { Oxalate } \\
\text { (mg/day) }\end{array}$ & $0,3 \pm 0,22$ & $0,4 \pm 0,03$ & $0,6 \pm 0,05$ & $0,5 \pm 0,05$ \\
\hline $\begin{array}{l}\text { Citrate } \\
\text { (mg/day) }\end{array}$ & $22,6 \pm 1,4$ & $20,2 \pm 3,2$ & $24,8 \pm 3,0^{*}$ & $15,3 \pm 2,2^{*}$ \\
\hline $\begin{array}{c}\text { Alkaline } \\
\text { Phosphatase } \\
\text { ( } \mu \mathrm{mol} / \mathrm{mg} \text { creat) }\end{array}$ & $0,57 \pm 0,02^{* *}$ & $0,79 \pm 0,04^{* *}$ & $0,69 \pm 0,05^{*}$ & $0,83 \pm 0,03^{*}$ \\
\hline
\end{tabular}


Glomerular, interstitial and sub-capsular hemorrhage, with perivascular edema was observed in the animals in both groups studied (Figures 1 to 3 ).

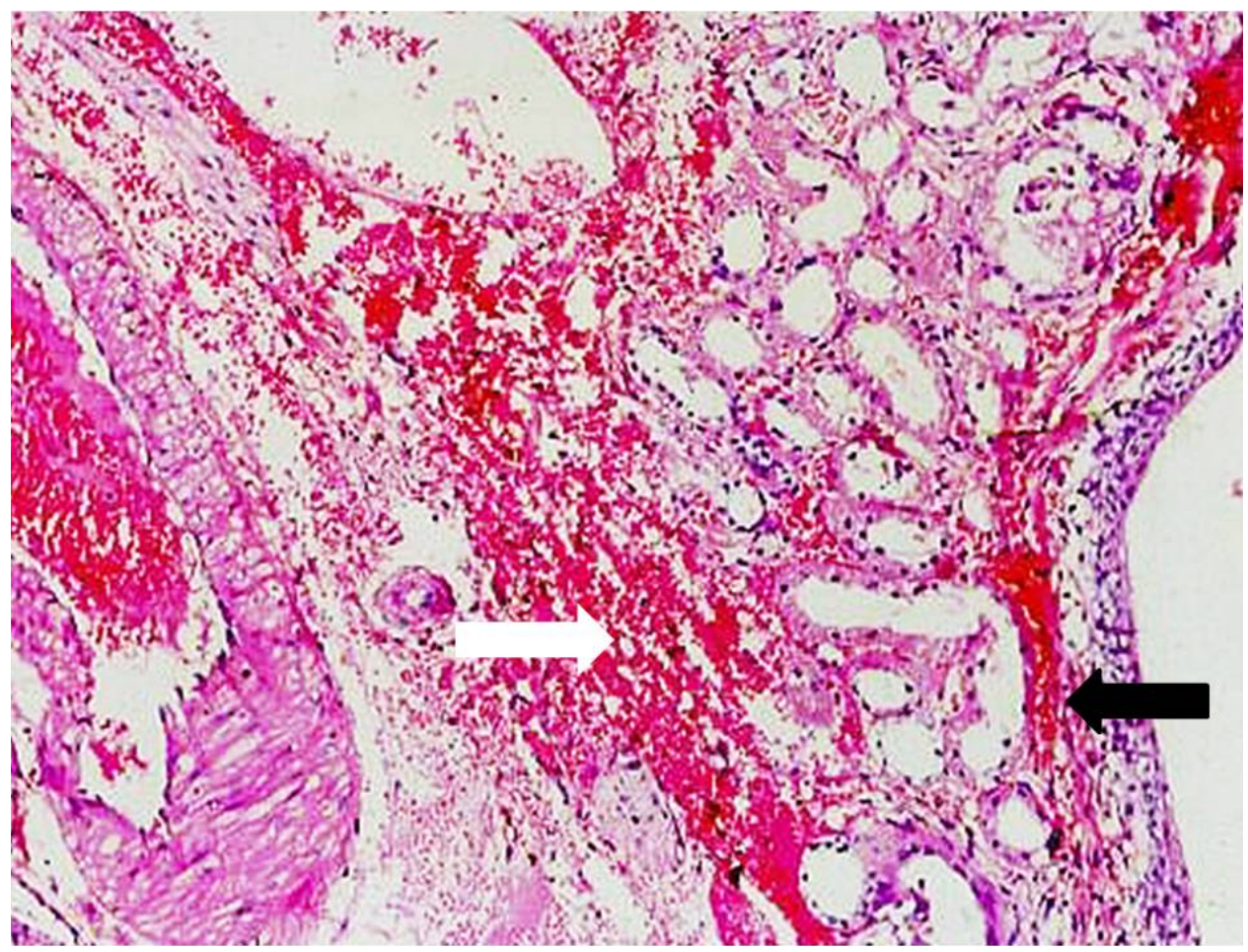

FIGURE 1 - Animal from Group 1 showing sub-capsular (black arrow) and intersticial hemorrhage (white arrow). H\&E. 40X

\section{Discussion}

Extracorporeal shock wave lithotripsy (ESW) has changed the management of urinary stones, since it is a non-invasive form of treatment that can be used in most patients, regardless of age ${ }^{23}$. Although ESW is safe and effective, studies in animal models and in humans have shown that tissue lesions may occur, altering the tubule function and reducing the renal blood flow ${ }^{24,25}$. The severity of such alterations is related, among further factors, to the number, intensity and type of shock waves administered ${ }^{26,27}$. The ischemia and inflammation that occur due to the trauma, contribute towards the appearance of fibrosis and loss of parenchymatous functional mass $^{28}$. Since they are focal lesions and due to the large renal functional reserve that usually remains, there is a small incidence of clinically apparent dysfunctions.

Determination of urinary excretion of some enzymes may serve as a non-invasive and even sensitive test for the occasional renal lesions. To that end several enzymes have already been put to the test. The alanine aminopeptidase enzyme increases when there is a major renal lesion, lactic dehydrogenase and n-acetylglucosaminidase increase in cases of renal cell or subjacent muscle lesion ${ }^{28-30}$. In this study, we used urinary alkaline phosphatase, an enzyme present on the surface of the proximal tubule brush border, as marker of the renal lesions resulting from the ESW. A significant increase in its urinary excretion could be detected in the animals in both groups, probably due to both the action of the shock waves and the proximal tubule repair and cicatrization mechanisms. Most likely, also due to those two reasons, no significant difference was found in the urinary excretion of alkaline phosphatase between both groups of animals. Those lesions were concomitant to the ones found in the histological exams.

A further problem that occurs in patients undergoing ESW is the increased rate of urinary stone recurrence following the treatment. Residual fragments have been found to be difficult to eliminate, even if 
smaller than five millimeters, as they may frequently migrate to the medium and lower calyces. Those small fragments start acting as a nucleus for the genesis of new stones ${ }^{31-34}$. Carr et al. ${ }^{35}$ compared the formation of residual stones in 298 patients treated with ESW, with 62 patients undergoing percutaneous nephrolithotomy. New stones were detected in 22\% of patients post-ESW against as few as $4.2 \%$ of the ones treated with percutaneous nephrolithotomy.

Alteration in urine tests may occasionally detect recurrence of the stone disease. Pierratos et al. ${ }^{36}$ tried to set a correlation between some serum and urinary biochemical parameters and the radiological evidence of post-ESW urinary stones. They found a smaller risk of growth or formation of new stones, in patients with high levels of urinary potassium during a two-year follow up period on average. They also observed greater citrate excretion in the urine, although not

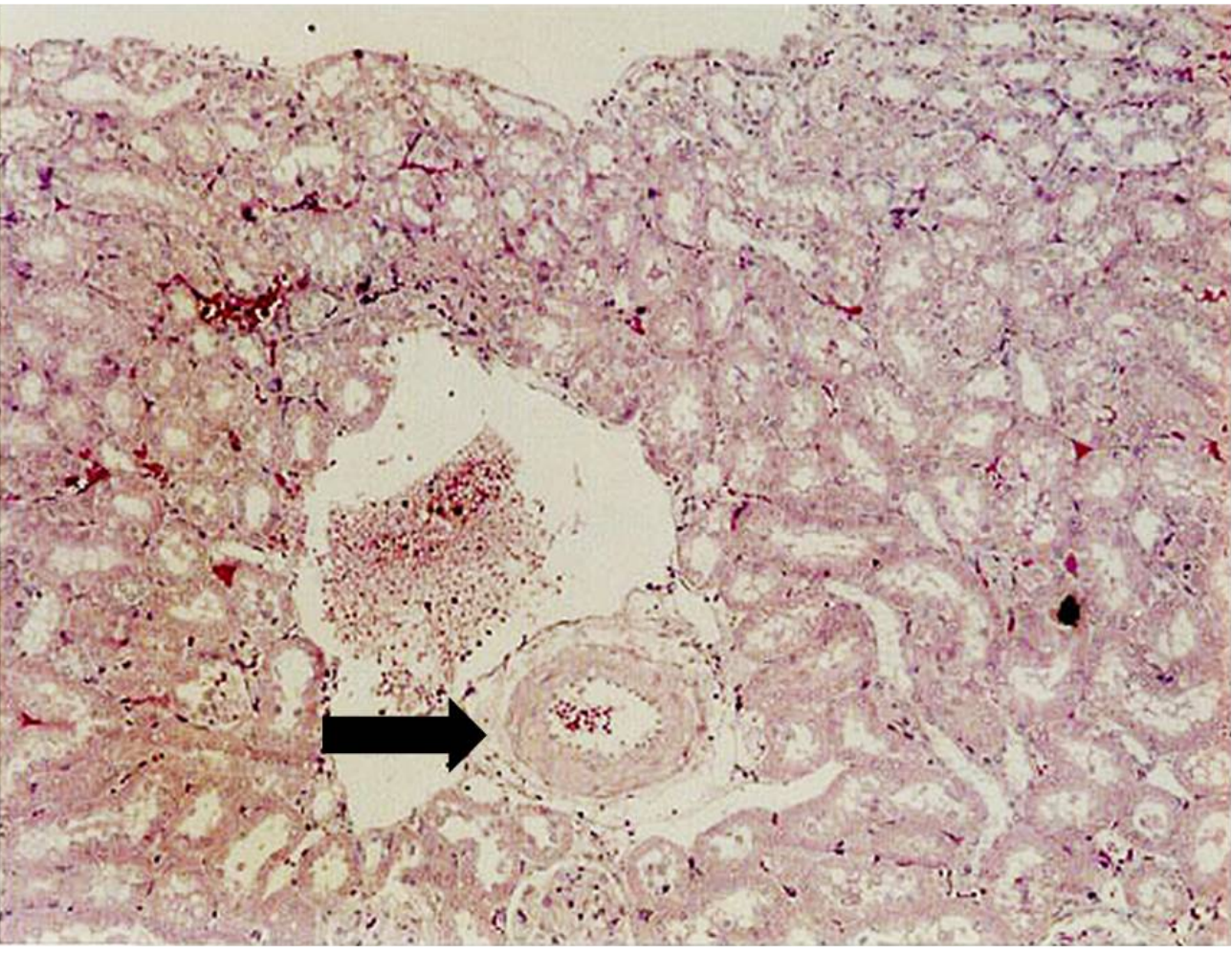

FIGURE 3 - Animal from Group 1 showing perivascular edema (arrow). H\&E. 40X statistically significant, in patients

who had not formed new stones or that presented with no growth in the pre-existing stones. More recently Sarica et al. ${ }^{37}$ assessed the effects of the treatment with potassium citrate in children to prevent new stones, based on the post-ESW remaining fragments. The children with residual fragments that received no treatment with potassium citrate had a significant formation of new stones after one year follow-up.

Citrate is an important inhibitor of urinary calculosis. It reduces urinary saturation as it forms complexes with calcium, inhibits spontaneous nucleation and delays the aggregation of oxalate crystals in vitro ${ }^{1}$. It is also a powerful growth inhibitor of calcium phosphate crystals, preventing the heterogeneous nucleation of calcium oxalate by monosodium urate crystals ${ }^{38}$. These biological properties turn the citrate into a potentially effective inhibitor of stone formation. The rats undergoing two sessions of ESW (group 2) were found, in this study, to present significantly decreased citraturia whereas citrate secretion was not altered in the urine of the rats undergoing just one application. This reduced citraturia in the animals undergoing more than one session of ESW is most likely due to the fact that the citrate is an enzyme predominantly of the proximal tubules, site where the lesions caused by the shock waves were mostly felt. Citraturia reductions like the ones found, even if transitory, may be a predisposing factor for lithogenesis.

A limitation in this study is the fact that a quite large area of the renal surface, larger than occurring in the daily clinical practice, is affected by ESW. It did show, however, that it is important to continue searching for sensitive markers of the occasional residual renal lesions that certainly must exist, and that the determination of the urinary citrate concentration can be a sensitive marker in the prevention of formation of new calculi following ESW therapy.

\section{Conclusions}

A significant increase in urinary alkaline phosphatase was found in both groups studied, suggesting a proximal tubule lesion. In the group of rats undergoing more than one ESW application, smaller urinary citrate excretion was observed, which can be a factor contributing towards the formation of new calculi.

\section{References}

1 - Moe OW. Kidney stones: pathophysiology and medical management. Lancet. 2006; 367:333-44.

2 - Costa-Bauzá A, Isern B; Perelló J, Sanchis P, Grases F. Factors affecting the regrowth of renal stones in vitro: a contribution to the understanding of renal stone development. Scand J Urol Nephrol. 2005; 39:194-9.

3 - Sun BY, Lee Y, Jiaan B, Chen K, Chang L, Chen K. Recurrence rate and risk factors for urinary calculi after extracorporeal shock wave lithotripsy. J Urol. 1996; 156:903-6.

4 - Renner C, Rassweiler J. Treatment of renal stones by extracorporeal shock wave lithotripsy. Nephron. 1999; 81(Suppl 1):71-81.

5 - Auge BK, Preminger GM. Update on shock wave litotripsy technology. Curr Opin Urol. 2002; 12:287-90.

6 - Paterson RF, Lifshitz DA, Lingeman JE, Evan AP, Connors BA, Fineberg NS, Williams JC Jr, McAteer JA. Stone fragmentation during shock wave lithotripsy is improved by slowing the shock wave rate: studies with a new animal model. J Urol. 2002; 168:2211-5.

7 - Coptcoat MJ, Webb DR, Kellett MJ, Fletcher MS, McNicholas TA, Dickinson IK, Whitfield HN, Wickham JE. The complications of extracorporeal shock wave lithotripsy: management and prevention. $\mathrm{Br}$ J Urol. 1986; 58:578-80.

8 - Roth RA, Beckmann CF. Complications of extracorporeal shock wave lithotripsy and percutaneous nephrolithotomy. Urol Clin North Am. 1988; 15:155-66. 
9 - Drach GW, Dretler S, Fair W, Finlayson B, Gillenwater J, Griffith D, Lingeman J, Newman D. Report of the United States Cooperative Study of extracorporeal shock wave lithotripsy. J Urol. 1986; 135:1127-33.

10 - Recker F, Rübben H, Bex A, Constantinides C. Morphological changes following ESWL in the rat kidney. Urol Res. 1989; 17:229-33.

11 - Weber C, Glück U, Staehler G, Retting R. Extracorporeal shock wave treatment raises blood pressure in borderline hypertensive rats. J Urol. 1995; 154:232-6.

12 - Neuerburg J, Daus HJ, Recker F, Bohndorf K, Bex A, Guenther R, Hofstaedter F. Effects of lithotripsy on rat Kidney: evaluation with MR imaging, histology and electron microscopy. J Comput Assist Tomog. 1989; 13:82-90.

13 - Dhar NB, Thornton J, Karafa MT, Streem SB. A multivariate analysis of risk factors associated with subcapsular hematoma formation following electromagnetic shock wave lithotripsy. J Urol. 2004; 172(6Pt1):2271-4. 14 - Khaitan A, Gupta NP, Hemal AK, Dogra PN, Seth A, Aron M. Post-ESWL clinically insignificant residual stones: reality or mith? Urology. 2002; 59: 20-4.

15 - Oehlschläger S, Albrecht S, Hakenberg OW, Schrödter S, Froehner M, Manseck A, Wirth MP. Early changes of oxalate and calcium urine excretion in those with calcium oxalate stone formation after extracorporeal shock wave lithotripsy. Urology. 2003; 62:17-21.

16 - Willis LR, Evan AP, Connors BA, Shao Y, Blomgren PM, Pratt JH, Fineberg NS, Lingeman JE. Shockwave lithotripsy: dose-related effects on renal structure, hemodynamics, and tubular function. J Endourol. 2005; 19:90-101.

17 - Karlsen SJ, Berg KJ. Acute changes in kidney function following extracorporeal shock wave lithotripsy for renal stones. Br J Urol. 1991; 67:241-5.

18 - Kirkali Z, Kirkali G, Tahiri Y. The effect of extracorporeal electromagnetic shock waves on renal proximal tubular function. Int Urol Nephrol. 1994; 26:255-7.

19 - Assimos DG, Boyce HW, Furr EG, Espeland MA, Holmes RP, Harrison LH, Kroovand RL. Selective elevation of urinary enzyme levels after extracorporeal shock wave lithotripsy. J Urol. 1989; 142:687-90.

20 - Karlin GS, Schulsinger D, Urivetsky M, Smith AD. Absence of persisting parenchymal damage after extracorporeal shock wave lithotripsy as judged by excretion of renal tubular enzymes. J Urol. 1990; 144:13-4. 21 - Fortes MA, Andriolo A, Ortiz V, Srougi M. Effect of shock wave reapplication on urinary $\mathrm{N}$-acetyl-beta-glucosaminidase in canine kidney. Int Braz J Urol. 2004; 30:148-54.

22 - Lingeman JE. Stone treatments: current trends and future possibilities. J Urol. 2004; 172(5 Pt 1): 1774.

23 - Marberger M. Urinary stones. Curr Opin Urol. 1999; 9: 315-7.
24 - Morris JS, Hussmann DA, Wilson WT, Preminger GM. Temporal effects of extracorporeal shock wave lithotripsy. J Urol. 1991; 145:881-3. 25 - Rassweiller J, Köhrmann KU, Back W, Fröhner S, Raab M, Weber, Kahmann F, Marlinghaus E. Experimental basis of shock wave-induced renal trauma in the model of canine kidney. World J Urol. 1993; 11:43-53. 26 - Koga H, Matsuoka K, Noda S, Yamashita T. Cumulative renal damage in dogs by repeated treatment with extracorporeal shock waves. Int J Urol. 1996; 3:134-40.

27 - Evan AP, Willis LR, Lingeman JE, Mc Ateer JA. Renal trauma and risk of long term complications in shock wave lithotripsy. Nephron. 1998; 78:1-8.

28 - Henneman PL, Bar'Or D, Marx JA. Urinary lactic dehydrogenase as a marker of renal injury in blunt trauma patients with hematuria. Ann Emerg Med. 1988; 17:797-800.

29 - Jung K, Kirschner P, Wille A, Brien G. Excretion of urinary enzymes after extracorporeal shock wave lithotripsy: a critical reevaluation. J Urol. 1993; 149:1409-13.

30 - Recker F, Hofmann W, Bex A, Tscholl R. Quantitative determination of urinary marker proteins: a model to detect intrarenal bioeffects after extracorporeal lithotripsy. J Urol. 1992; 148(3Pt2):1000-6.

31 - Rutz-Danielczak A, Pupek-Musialik D, Raszeja-Wanic B. Effects of extracorporeal shock wave lithotripsy on renal function in patients with kidney stone disease. Nephon. 1998; 79:162-6.

32 - Sen S, Erden Y, Oymak O, Yalçin AU, Turgan C, Ersoy H, Bingöl N, Tamer S. Effects of extracorporeal shock wave lithotripsy on glomerular and tubular functions. Int Urol Nephrol. 1996; 28:309-13.

33 - Candau C, Saussine C, Lang H, Roy C, Faure F, Jacgmin D. Natural history of residual renal stone fragments after ESWL. Eur Urol. 2000; $37: 18-22$.

34 - Osmann MM, Alfano Y, Kamp S, Haecher A, Alken P, Michel MS, Knoll T. 5-year follow-up of patients with clinically insignificant residual fragments after extracorporal shockwave lithotripsy. Eur Urol. 2005; 47:860-4.

35 - Carr LK, D’A Honey J, Jewett MA, Ibanez D, Ryan M, Bombardier C. New stone formation: a comparison of extracorporeal shock wave lithotripsy and percutaneous nephrolithotomy. J Urol. 1996; 155:1565-7. 36 - Pierratos A, Dharamsi N, Carr LK, Ibanez D, Jewett MA, Honey RJ. Higher urinary potassium is associated with decreased stone growth after shock wave lithotripsy. J Urol. 2000; 164:1486-9.

37 - Sarica k, Erturhan S, Yurtseven C, Yagci F. Effect of potassium citrate therapy on stone recurrence and regrowth after extracorporeal shockwave lithotripsy in children. J Endourol. 2006; 20:875-9.

38 - Pak CY. Citrate and renal calculi: an update. Miner Electrolyte Metab. 1994; 20:371-7.

Conflict of interest: none Financial source: none

\section{Correspondence:}

Dr. Luiz G. Freitas Filho

Rua Batista Cepelos 87/61

04109-120 Sao Paulo - SP Brazil

Phone / Fax: (55 11)5083-5952

luizfreitasf@hotmail.com

1freitasf@terra.com.br

Received: May 21, 2009

Review: July 15, 2009

Accepted: August 14, 2009

\section{How to cite this article}

Carvalho M, Freitas Filho LG, Carvalho M, Fagundes DJ, Ortiz V. Effects of repeated extracorporeal shock wave in urinary biochemical markers of rats. Acta Cir Bras. [serial on the Internet] 2009 Nov-Dec;24(6). Available from URL: http://www.scielo.br/acb 